\title{
Growth Response and Production of Broccoli (Brassica oleracea) With Application of Azolla Composting at Several Plant Spacing
}

\author{
Wan Arfiani Barus, Hadriman Khair, and Fatrian \\ Departement of Agrotechnology, Faculty of Agriculture, University of Muhammadiyah Sumatera Utara, \\ Indonesia
}

\begin{abstract}
This study aims to determine the growth response and Plant Production of Broccoli (Brassica oleracea Var. Botrytis) with application of Azolla composting in some plant spacing. This research used a Factorial Randomized Block Design with two factors namely: Azolla Composting Factor (A) with 4 levels 0, 32, 64, 96 and A4 $=128 \mathrm{~g} / \mathrm{plant}$. Plant spacing factor with 3 levels $45 \mathrm{~cm} \times 45 \mathrm{~cm}, 50 \mathrm{~cm} \times 50 \mathrm{~cm}$ and $55 \mathrm{~cm} \times 55$. The results showed that the application of Azolla compost $128 \mathrm{~g} /$ plant had significant effect on the stem height, stem diameter and flower weight. Plant spacing in $55 \mathrm{~cm}$ x $55 \mathrm{~cm}$ only affected the flower weight. There was no interaction between Azolla compost and plant spacing for all parameter observed.
\end{abstract}

Keywords: Azolla, broccoli, compost, plant spacing

Received 03 August 2018 | Revised 10 August 2018 | Accepted 16 August 2018

\section{Introduction}

Broccoli is a plant from the cabbage or Brassicaceae. The part consumed from this plant is the interest. Broccoli is a horticultural plant that is a source of vitamins A, B complex, C, calcium, iron and essential minerals for the fulfilment of human nutrition and contains substances that can prevent cancer [1] and [2]. Increasing demand for broccoli along with changes in the lifestyle of people who are increasingly aware of the importance of a healthy lifestyle [3]. However, according to statistics center bureau of Karo Regency, the production of broccoli in Karo Regency decreased by $5.28 \%$ from 2008 to 2012 with constant planting area. Based on Minister of Agriculture Regulation No. 64/Permentan/OT.140/2013, and SNI 6729: 2013, an organic farming system is a holistic production management system to improve and develop agro-ecosystem health, including biodiversity, biological cycle, and soil biological activity. Organic farming emphasizes the application of management practices that prioritize the use of inputs from the waste of cultivation activities on the land, taking into account the adaptability to

*Corresponding author at: Department of Agrotechnology, Faculty of Agriculture, Universitas Muhammadiyah Sumatera Utara, Jl. Kapten Muchtar Basri No. 108-112, Medan, Sumatera Utara, Indonesia

E-mail address: wanarfianibarus@umsu.a.cid 
local conditions. Where feasible it can be achieved by the use of cultural, biological and mechanical methods that do not use synthetic materials to meet special needs in the system.

In order for Indonesian broccoli to compete in the international market, the quality of broccoli should be increased through organic farming. Purwanti [4] reported that the results show that the cultivation of mustard plants fertilized using organic fertilizer (manure) gives better quality results compared to the use of inorganic fertilizers.

Azolla is very appropriate as a substitute for organic fertilizer because with the rapid growth of this plant has high organic productivity and has the highest $\mathrm{N}, \mathrm{P}$ and $\mathrm{K}$ content compared to other organic sources. Therefore the use of organic materials as nutrients is very important for soil and plants. In addition to providing good crop production, Azolla can also improve soil structure [5].

Besides acting as nitrogen-fixing $(\mathrm{N})$, Azolla compost also contains other nutrients that are quite high and complete, with an average $\mathrm{C} / \mathrm{N}$ ratio of $15-18 \%$. The nutrient contained in compost Azolla is Nitrogen (N) 0.50-0.90\%, Phosphor (P) 4.00-5.00\%, Potassium (K) 2.00-4.50\%, Calcium (Ca) 0.40-1.00\%, Magnesium (Mg) 0.50-0.60\%, Manganese (Mn) 0.11-0.16\%, Ferrum (Fe) $0.16-0.50 \%$, and $\mathrm{C} / \mathrm{N}$ ratio $15-18 \%$ [6]. The high nutrient content in the Azolla compost makes this water nail plant suitable for use as an organic fertilizer and can be relied upon to support the concept of organic farming. Giving Azolla to the cultivation of rice crops before planting can increase rice yield 35\% -58\% [7]. In addition to nutrient availability, the factor of cultivation techniques also greatly determines the increase in Broccoli yield, including the factor of plant spacing. The regulation of plant population through the spacing of plants in a plant will affect the efficiency of plants in utilizing the sun and crop competition in the use of nutrients and water which will ultimately affect the growth and production of crops. With good plant spacing arrangements, existing space utilization for plant growth and buffer capacity for adverse events can be efficient. Based on the above, it is necessary to conduct a study to determine the effect of the Azolla compost application and plant spacing system on the growth and production of Broccoli.

\section{Materials and Methods}

The research was conducted at Vegetable Plant Research Institute of Tongkoh Village, Brastagi, Karo Regency, from March 2017 to June 2017. The materials used are broccoli seed variety Lucky, Azolla compost, manure, Bioactivator, water, Insecticide Antracol 70 WP, Upsell Insecticide 240 EC and Prevathon Fungicide 50 SC. The tools used in this study were hoes, broach, meters, scales, hand sprayer, plastic straps, buckets, bamboo, name signs, knives, samples and stationery. 
This research used a factorial randomized block design with two factors, i.e.:

a. Dosage of Azolla compost, consist of 4 levels:

$$
\begin{aligned}
& \mathrm{A} 0=0 \mathrm{~g} / \mathrm{plant} \\
& \mathrm{A} 1=32 \mathrm{~g} / \text { plant } \\
& \mathrm{A} 2=64 \mathrm{~g} / \text { plant } \\
& \mathrm{A} 3=96 \mathrm{~g} / \mathrm{plant} \\
& \mathrm{A} 4=128 \mathrm{~g} / \text { plant }
\end{aligned}
$$

b. Plant spacing, consist of 3 combinations:

$$
\begin{aligned}
& \mathrm{J} 1=45 \mathrm{~cm} \times 45 \mathrm{~cm} \\
& \mathrm{~J} 2=50 \mathrm{~cm} \times 50 \mathrm{~cm} \\
& \mathrm{~J} 3=55 \mathrm{~cm} \times 55 \mathrm{~cm}
\end{aligned}
$$

\begin{tabular}{|c|c|c|c|c|c|c|}
\hline \multirow{3}{*}{ Plant Spacing } & \multicolumn{5}{|c|}{ Compost of Azolla } & \multirow{3}{*}{ Mean } \\
\hline & A0 & A1 & $\mathbf{A 2}$ & A3 & A4 & \\
\hline & \multicolumn{5}{|c|}{ - } & \\
\hline $\mathrm{J} 1(45 \mathrm{~cm} \mathrm{x} 45 \mathrm{~cm})$ & 44.00 & 44.40 & 45.80 & 44.20 & 47.07 & 45.09 \\
\hline $\mathrm{J} 2(45 \mathrm{~cm} \times 45 \mathrm{~cm})$ & 43.07 & 43.07 & 45.07 & 47.80 & 47.13 & 45.23 \\
\hline $\mathrm{J} 3(45 \mathrm{~cm} \mathrm{x} 45 \mathrm{~cm})$ & 43.33 & 44.80 & 44.20 & 46.07 & 48.60 & 45.40 \\
\hline Mean & $43.47^{\mathrm{b}}$ & $44.09^{\mathrm{b}}$ & $45.02^{\mathrm{ab}}$ & $46.02^{\mathrm{a}}$ & $47.60^{\mathrm{a}}$ & 45.24 \\
\hline
\end{tabular}

\section{Results and Discussion}

Based on the result of this research, it was found that the treatment of azolla compost application affected plant height. However, testing some plant spacing does not affect the height of Broccoli plants (Table 1). Table 1, it showed that azolla compost only had significant effect on plant weight 8 Week After Planting (WAP).

Table 1. Plant Height of Broccoli by Azolla Compost Application on 8 WAP

Note: The numbers followed by unequal letters on the same rows differ significantly according to the DMRT Test $5 \%$

Based on Table 1 it can be seen that the highest plant height is in the A4 treatment (Azolla 128 $\mathrm{g} / \mathrm{plant}$ compost) of $47.60 \mathrm{~cm}$ which is significantly different from the treatment A1 $(44.09 \mathrm{~cm})$ and A0 $(43.47 \mathrm{~cm})$ but not different significantly to the treatment of A3 $(46.02 \mathrm{~cm})$ and A2 $(45.02 \mathrm{~cm})$. Compost Azolla has an excellent nutrient content for plants in the process of growth and development of plants and has a high nitrogen content that can replace the urea fertilizer. According to Pasaribu [8] and Tuturoong [9], Azolla contains various essential nutrients, such as $\mathrm{N}, \mathrm{P}, \mathrm{K}, \mathrm{Ca}, \mathrm{Mg}$, and $\mathrm{S}$, as well as microelements such as $\mathrm{Fe}, \mathrm{Zn}, \mathrm{Mn}, \mathrm{Co}, \mathrm{Na}, \mathrm{Cl}$, other.

Furthermore, application Azolla compost only significant effect on the number of plants leaves aged 3 WAP, and spacing significantly affects the number of the leaf of Broccoli plant age 3 WAP and 4 WAP. The interaction of the two treatment factors gave no significant effect on the number of leaves of 2, 3, 4, 5, 6, 7 and 8 WAP. This is suspected because when the research, the 
growth of plants is disturbed due to the temperature is not optimal which can affect the growth of plants so that organisms contained in organic materials cannot supply food for organisms in the soil such as molds, bacteria, actinomycetes, and protozoa so it can hamper the process decomposition of organic materials such as that according to Mamduh, [10] and Pasaribu [8] reported that the hummus in the Azolla compost contains nutrients needed by plants. In addition, hummus is a cation buffer that can retain nutrients as food for plants. Compost also serves as a food supplier for organisms in the soil that can increase and accelerate the process of decomposition of organic materials. Based on the results of analysis of variance (ANOVA) with Randomized Block Design showed that Azolla compost only had the significant effect on 6 and $8 \mathrm{MST}$, while on spacing application and interaction of both factors gave no significant effect on stem diameter 2, 4, 6, and 8 WAP. Data diameter of the stem at age 8 MST can be seen in Table 2 below.

Table 2. Stem Diameter of Broccoli by Azolla Compost Application in some Plant Spacing on 8 WAP

\begin{tabular}{ccccccc}
\hline Plant & \multicolumn{5}{c}{ Compost of Azolla } & \multirow{2}{*}{ Mean } \\
\cline { 2 - 5 } Spacing & $\mathbf{A 0}$ & $\mathbf{A 1}$ & $\mathbf{A 2}$ & $\mathbf{A 3}$ & $\mathbf{A 4}$ & \\
\hline J1 & 1.24 & 1.23 & 1.30 & 1.27 & 1.27 & 1.26 \\
J2 & 1.25 & 1.31 & 1.26 & 1.28 & 1.31 & 1.28 \\
J3 & 1.25 & 1.23 & 1.27 & 1.32 & 1.32 & 1.28 \\
\hline Mean & $1.25^{\mathrm{b}}$ & $1.26^{\mathrm{ab}}$ & $1.28^{\mathrm{ab}}$ & $1.29^{\mathrm{a}}$ & $1.30^{\mathrm{a}}$ & 1.27 \\
\hline
\end{tabular}

Note: The numbers followed by unequal letters on the same rows differ significantly according to the DMRT Test $5 \%$

Based on Table 2 it can be seen that the highest stem diameter with azolla compost was found in A4 treatment of $1.30 \mathrm{~cm}$ which was significantly different from the A0 treatment $(1.25 \mathrm{~cm})$ but not significantly different from the A3 treatment $(1.29 \mathrm{~cm}) \mathrm{A} 2$ $(1.28 \mathrm{~cm})$ and A1 $(1.26 \mathrm{~cm})$. Furthermore, base on regression and correlation analysis, the relationship of Azolla composting application on stem diameter can be seen in Figure 1 below.

The graph in Figure 1 showed that the stem diameter of Broccoli plants has increased along with the dose increase of the Azolla composted and the graph showing a positive linear relationship with the regression equation $\hat{y}=1.25+0.013 \mathrm{~A}$ with $\mathrm{r}=0.982$. Compost Azolla including organic fertilizer that is widely used as a basic fertilizer in plants. Application of organic matter in the soil can improve the physical, chemical and biological properties of soil affecting nutrient uptake by plant roots. Loevici [11] and Kementerian Pertanian Republik Indonesia [12] reports that basically, the application of organic matter into the soil will affect the physical, biological, and chemical properties of the soil. The role of organic matter to the soil physical properties such as stimulate granulation, improve soil aeration, and increase the ability to hold water. The role of 
organic matter to soil biological properties is to increase microorganism activity which contribute to nitrogen fixation and certain nutrient transfer such as $\mathrm{N}, \mathrm{P}, \mathrm{K}$, and $\mathrm{S}$. The role of organic matter to soil chemical properties is to increase cation exchange capacity so that it can affect nutrient uptake by plants.

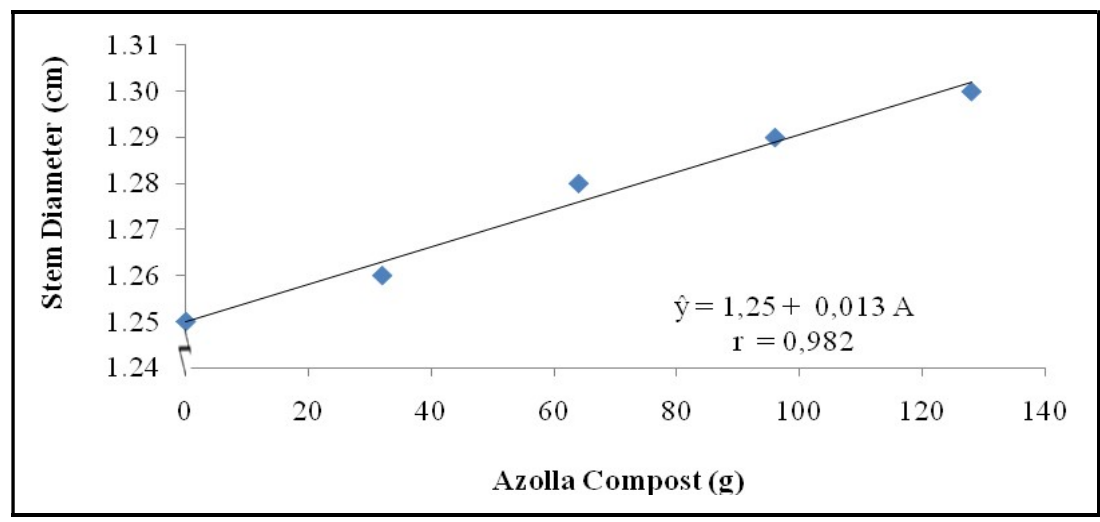

Figure 1. Stem Diameter of Broccoli with Azolla Composting Application

Furthermore, based on the results of analysis of variance with Randomized Block Design showed that Azolla composting and spacing application and interaction of both factors gave no significant effect on flowering age of broccoli plants.

Table 3. Age Flowering of Broccoli by Azolla Compost Application in Plant Spacing on 8 WAP

\begin{tabular}{ccccccc}
\hline \multirow{2}{*}{ Plant Spacing } & \multicolumn{5}{c}{ Compost of Azolla } & \multirow{2}{*}{ Mean } \\
\cline { 2 - 6 } & $\mathbf{A 0}$ & $\mathbf{A 1}$ & $\mathbf{A 2}$ & $\mathbf{A 3}$ & $\mathbf{A 4}$ & \\
\hline J1 & 134.40 & 190.60 & 198.07 & 188.80 & 318.60 & $206.09^{\mathrm{b}}$ \\
J2 & 136.33 & 186.27 & 157.33 & 214.33 & 245.07 & $187.87^{\mathrm{b}}$ \\
J3 & 229.93 & 214.53 & 256.87 & 231.27 & 274.53 & $241.43^{\mathrm{a}}$ \\
\hline Mean & $166.89^{\mathrm{b}}$ & $197.13^{\mathrm{b}}$ & $204.09^{\mathrm{b}}$ & $211.47^{\mathrm{b}}$ & $279.40^{\mathrm{a}}$ & 211.80 \\
\hline
\end{tabular}

Note: The numbers followed by unequal letters on the same rows differ significantly according to the DMRT Test $5 \%$

The inactivity of Azolla compost and the application of plant spacing and the interaction of the two treatments is due to the insufficient nutrient availability for the plant within a certain time but the decomposition process of organic materials in the soil. Lack of nutrients associated with age began to flower the old, so the plants do not get the food in accordance with their needs and vegetative phase of the longer plants that resulted in plants not flowering in time. In accordance with opinion Rismunandar [13] and Fitriani [14] that with sufficient nutrient needs both macro and micro nutrients, the development and productivity of the plant will run smoothly.

The inactivity of Azolla compost and the application of plant spacing and the interaction of the two treatments is due to the insufficient nutrient availability for the plant within a certain time but the decomposition process of organic materials in the soil. Lack of nutrients associated with 
age began to flower the old, so the plants do not get the food in accordance with their needs and vegetative phase of the longer plants that resulted in plants not flowering in time. In accordance with opinion Rismunandar [13] that with sufficient nutrient needs both macro and micro nutrients, the development and productivity of the plant will run smoothly.

The application of Azolla compost and the plant spacing system was affected the weight of Broccoli flowers. A4(128 g/plant) Azolla compost produced the highest broccoli flower weight of $279.40 \mathrm{~g}$ which was significantly different from A3 treatment (211.47 g), A2 (204.09 g), A1 $(197,13 \mathrm{~g})$ and A0 (166.89 g). While the weight of flower with the highest average with the application of spacing is found in treatment $\mathrm{J} 3$ is $241.43 \mathrm{~g}$ which is significantly different in treatment J2 (187.87 g) and J1 (206.09 g). Using regression and correlation analysis, the azolla composting relationship can be seen in Figure 2 below.

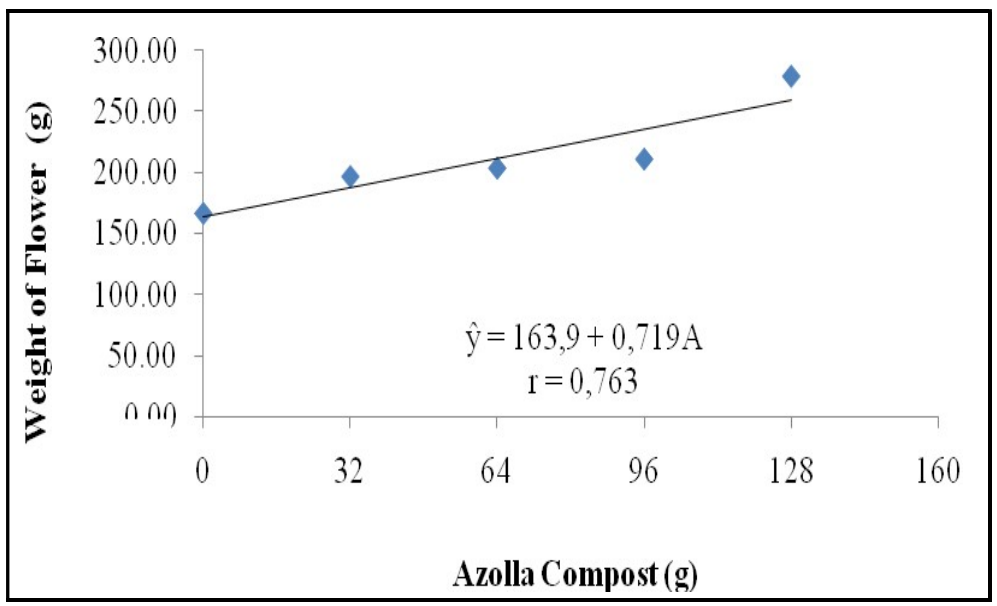

Figure 2. Weight of Broccoli Flower with Application of Azolla Composting

Figure 2 shows that the weight of the flower increases with increasing doses of azolla compost and shows a positive linear relationship with the regression equation $\hat{y}=163.9+0.719 \mathrm{~A}$ with $\mathrm{r}$ $=0.763$. Using regression and correlation analysis, the azolla composting relation can be seen in Figure 3.

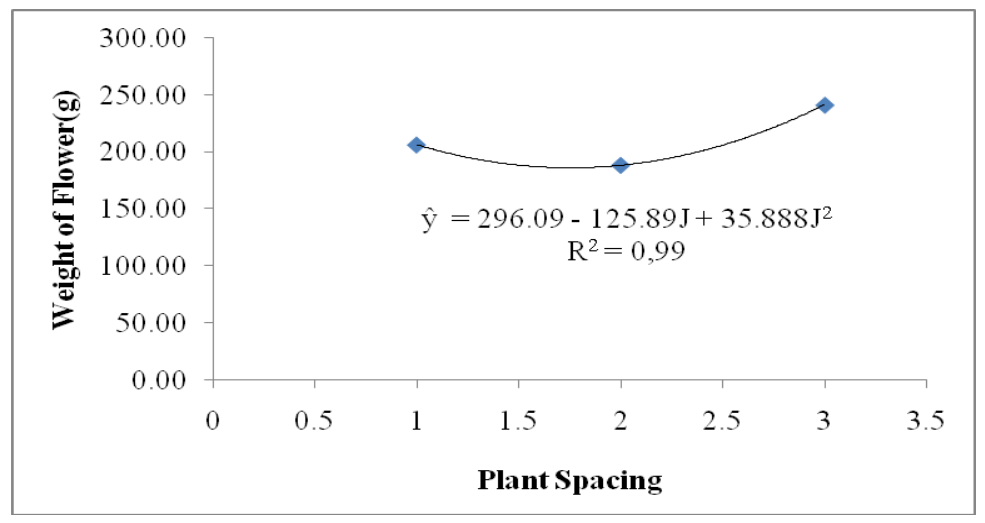

Figure 3. Weight of Broccoli Flower in Several Plant Spacing 
Figure 3 shows that the weight of interest has increased along with the weight of interest applied by spacing showing a positive linear relationship with the regression equation $\hat{y}=296.09$ $125.89 \mathrm{~J}+35.888 \mathrm{~J} 2$ with value $\mathrm{R}=0.99$.

Based on the equation, the best interest weight on Azolla compost application was found on A4, while the best spacing application is obtained in J3. This is because in line with the vegetative growth of the plant, the better the vegetative growth of the plant then the generative growth will also be good too. This is in accordance with what was reported by Marliah, [15] and Mawazin and Suhendi [16] that this is closely related to the availability of balanced nutrients in the soil, thus affecting vegetative and generative growth of plants, especially the weight of flowers. Explained by Mamduh [10], Azolla compost has a very important influence in improving soil chemical and physical properties, provides nutrients for plants and helps to improve soil's ability to retain water, so that the process of photosisntesis in the plant goes well and direct assimilate results can be utilized. Meanwhile, according to Musa, [17) through the arrangement of plant spacing on a plant will affect the efficiency of plants in utilizing the sun and the competition of plants in the utilization of nutrients and water that will ultimately affect the growth and production of plants. With good plant spacing arrangements, existing space utilization for plant growth and buffer capacity for adverse events can be streamlined.

\section{Conclusion}

Application of Azolla compost $128 \mathrm{~g} /$ plant effect on stem height, stem diameter and flower weight. Application of spacing $55 \mathrm{~cm}$ x $55 \mathrm{~cm}$ only affected the weight of flower. There was no interaction between application of Azolla compost and the plant spacing system to all parameters observed.

\section{REFERENCES}

[1] C. Wasnowati, "Kajian saat pemberian pupuk dasar nitrogen dan umbi bibit pada tanaman brokoli (Brassica oleraceae L)," AGROVIGOR, vol. 3, no. 1, pp. 14-22, 2009.

[2] N. Yenti, A. Firas, and Aminah "Teknologi produksi tanaman hortikultura: Budidaya tanaman brokoli," Makalah, Fakultas Pertanian UNAND, Padang, 2016.

[3] M. Gardjito, W. Handayani, and R. Salfarino, Penanganan Segar Hortikultura untuk Penyimpanan dan Pemasaran. Jakarta: Prenadamedia Group, 2015.

[4] D. Purwanti, "Pengaruh macam dan konsentrasi pupuk organik terhadap pertumbuhan dan hasil tanaman sawi hijau," Skripsi, Fakultas Pertanian UNS, Surakarta, 2008.

[5] Direktorat Jendral Perkebunan, "Prospek Azolla Sebagai Pupuk Hijau Penghasil Nitrogen," Balai Besar Perbenihan dan Proteksi Tanaman Perkebunan. [Online]. Available: www.ditjenbun.pertanian.go.id

[6] S. Djojosuwito, “Azolla. pertanian organik dan multigna,” Jurnal Kanisius, vol. 39, no. 22, pp. 11-36, 2010. 
[7] Haryanto, "Pemanfaatan azolla sebagai sumber nitrogen terbarukan dalam sistem budidaya padi sawah yang ramah lingkungan," Laporan tahap akhir. Laporan kemajuan program insentif. Pusat Aplikasi Teknologi Isotop dan Radiasi. BATAN, 2010.

[8] E. A. Pasaribu, "Pengaruh waktu aplikasi dan pemberian berbagai dosis kompos Azolla (Azolla $s p$ ) terhadap pertumbuhan dan produksi tanaman kailan (Brassica oleraceae var. Acephala)," Skripsi, Fakultas Pertanian USU, Medan, 2009.

[9] M. E. Tuturoong-Tulung, "Pemanfaatan Azolla sebagai pupuk organik pada budidaya padi sawah," Warta Wiptek, no. 36, 2010.

[10] A. Mamduh, D. M. Endang, and A. A. Mochammad, "Pengaruh pemberian pupuk Azolla pinnata terhadap kandungan klorofil pada Dunaliella salina," Skripsi, Fakultas Perikanan dan Kelautan Airlangga, Surabaya, 2012.

[11] H. Loevici, "Improving soil fertility through organic recycling: A manual of rural composting," FAO, The United Nation, Rome, 2012.

[12] Kementan, "Sistem pertanian organik," Peraturan Menteri Pertanian. Kementerian Pertanian RI, 2013.

[13] Rismunandar, Tanah dan Seluk-beluknya Bagi Pertanian. Bandung: Sinar Baru, 2009.

[14] M. L. Fitriani, "Budidaya tanaman kubis bunga (Brassica oleraceae var. Botrytis) di Kebun Benih Hortikultura (KBH) Tawamanggu," Skripsi, Fakultas Pertanian UNS, Surakarta, 2009.

[15] A. Marliah., T. Hidayat, and N. Husna, "Pengaruh varietas dan jarak tanam terhadap pertumbuhan kedelai (Glycine max L)," Skripsi, Fakultas Pertanian UNSIYAH, Banda Aceh, 2011.

[16] Mawazin and H. Suhendi, "Pengaruh jarak tanam terhadap pertumbuhan diameter shorea parrifolia dyer. pusat penelitian dan pengembangan hutan dan konservasi alam," Jurnal Penelitian Hutan dan Konservasi Alam, vol. 5, no. 4, pp. 381-388, 2008.

[17] Y. Musa, M. A. Nasaruddin, and Kuruseng, "Evaluasi produktifitas jagung melalui pengolahan populasi tanaman, pengolahan tanah dan pemupukan," Agrisistem, vol. 3, no. 1, pp. 21-23, 2007. 